Article

\title{
The Influence of Socio-Demographic Factors on Financial Sustainability of Public Services: A Comparative Analysis in Regional Governments and Local Governments
}

\author{
María Deseada López Subires *, Laura Alcaide Muñoz, Andrés Navarro Galera and \\ Manuel Pedro Rodríguez Bolívar(i) \\ Department of Accounting and Finance, University of Granada, Campus Universitario de Cartuja, s/n, \\ 18071 Granada, Spain; lauraam@ugr.es (L.A.M.); angalera@ugr.es (A.N.G.); manuelp@ugr.es (M.P.R.B.) \\ * Correspondence: desirels@ugr.es
}

Received: 17 September 2019; Accepted: 24 October 2019; Published: 29 October 2019

\begin{abstract}
In recent years, financial sustainability (FS) of public policies has become a key concept in all governmental levels due to the need for ensuring public services delivery for future generations. Prior research has been focused on the financial sustainability in local governments (LGs) although its findings suggested the need to analyze this magnitude in other levels of government because political decisions could be different in each type of public entity. So, FS has also become very relevant in the Regional Government (RGs) context because their public policies affect not only at the regional level but also the local one. Therefore, from a comparative approach, this paper seeks to identify socio-demographic factors which could influence on the financial sustainability, in the Spanish context for both LGs vs. RGS in order to establish public policies to make sustainable public goods and services. Findings demonstrate that differences in influential factors between these two levels of public administration exist: factors such as population size and foreign population could have an effect on the financial sustainability of both governmental levels while the unemployment rate, dependent population, and population density affect differently on LGs and RGs.
\end{abstract}

Keywords: financial sustainability; intergenerational equity; influential factors; local governments; regional governments

\section{Introduction}

International Organizations have mentioned that the financial and economic crisis have undercut the capacity of governments to keep providing public services at any level of government. Indeed, the unsustainable tendency of all the governmental levels to spend more than they collect has created significant imbalances in the economic growth among the levels of governments and regions [1-6].

Under this background, although the concept of sustainability covers three dimensions (environmental, social and economic) [7], the financial sustainability becomes a key dimension in the management of governmental organizations in many parts of the world [8-12]. In this sense, governments, at any level (local, regional and state), are called to play a key role in promoting sustainable development, through environmental, economic and social policies based on the financial sustainability of public services $[13,14]$. Therefore, the financial sustainability analysis in each level of government could help to support an efficient process of making appropriate decisions and improving their quality and encourage the economic growth necessary for the well-being of future generations $[15,16]$.

In this context, International Organizations (EU, IMF, IFAC, CICA, NAO) and citizens have increased the demand for higher-quality public sector financial information, as premises of the 
Stakeholders Theory explain. The pressure on all levels of governments has increased to monitor public finances with the aim at reaching the major challenge of re-establishing the sustainable equilibrium between income and expenditures [9,17-20], making sense the Stakeholders and Institutional Theory.

In parallel, the financial statements have been recognized as very useful for informing about the financial sustainability of public policies [5,21,22]. Especially, IFAC (2013) have defined the Income Statement as a useful tool to assess the financial sustainability in public administrations due to its strong link to the intergenerational equity concept which is considered as the main condition to reach financial sustainability since it considers the future generations $[5,9,22,23]$. Therefore, the Income Statement becomes a key tool with a twofold objective, first to identify the capacity of the government to keep providing at least the same amount of public goods and services and second, the public resources that will be required to meet its public services delivery obligation in the future [22].

In addition, following the pronouncements of International Organizations [21,22] and the previous research $[20,24,25]$ it is essential to find out the drivers and risk factors of the financial sustainability in order to help public managers and politicians to take decisions to adequately manage the threats and opportunities to maintain the sustainability of public services over time.

Prior research has centred on the financial sustainability in local governments (LGs) leaving aside the study of this concept in other levels of governments, such as regional governments (RGs), although its findings raised the need to compare the financial sustainability in different governmental levels $[10,17,24,26]$. So, analysing the behaviour of each potential financial sustainability factor taking into account the different governmental levels (LGs and RGs) has become interesting to understand the financial position of a whole country, because the political decisions to be adopted could be different at each level. So, this paper contributes to prior research with a comparative analysis of financial sustainability in different levels of administrations focusing on the LGs and RGs, with the aim of promoting public policies to support public services at regional and even at the local level.

To achieve this aim, we focus our empirical research on the Spanish setting for two major reasons. Firstly, because following the Stability and Growth Pact developed by the European Union, the sustainability gap of Spain was, during the studied period, above the European Union average, in the short, medium and long term [27], which makes the study of the financial sustainability in this country particular timely and relevant. Secondly, because Spain public sector is composed of three levels: The State Government, 17 RGs and 8,124 LGs. Their interrelationship is based on competences; thus, each governmental level must meet their competences and they are not hierarchised. However, as the Bank of Spain has explained, this country has suffered a duplication in the delivery of services between these governmental levels (LGs and RGs), oversizing the public sector size and increasing the public revenues and expenditures because Spanish RGs are responsible for services as health, education, social affairs, employment or roads $[3,20,28,29]$.

Therefore, in this paper, we will consider RGs to be compared with LGs because they are in charge of managing regional public policies and providing the public services set out in their competences, and even they have to fund some public services at the local level.

Likewise, in Spain due to their economic gaps, the Law 2/2012, Stability and Financial Sustainability [27] has established different targets of deficit, debts, and expenditures for each governmental level. However, even establishing this regulatory reform on the size and volume of services provided, only LGs have been able to meet their proposes in recent years [28].

Therefore, a comparative analysis about the financial sustainability and its factors in the different levels of governments such as LGs and RGs could help to understand the financial situation of a country and to know how each level of government should face the different challenges to achieve the financial sustainability. However, up until now, previous research has not performed this comparative analysis, studying only the influential financial sustainability factors in LGs $[17,20,26]$.

Therefore, this paper attempts, firstly, to bridge the gap in the research about the broader concept of sustainability [7] focusing on its economic dimension through public financial sustainability. Secondly, to make a comparative analysis of financial sustainability and its influential factors (drivers and risk 
factors) in LGs and RGs. Concretely, this research tries to analyse the similarities and the differences between LGs and RGs regarding financial sustainability and its socio-demographic factors. So, our findings could bring new knowledge about the influential variables in the financial sustainability of LGs and RGs, which is very useful knowledge for the decisions of policymakers, practitioners, taxpayers, users of public services, voters and others stakeholders.

This paper is organized as follows. The following section explains the concept of financial sustainability and identifies the possible socio-demographic factors for financial sustainability in public administrations. The following section deal with the explanation of the sample, the variables, and the research methodology used. Then, results and findings are analysed. Finally, discussions and conclusions are debated in the last section of the paper.

\section{Research Hypothesis about Influential Factors on Financial Sustainability}

The impact of the economic and financial crisis on public administrations has led International Organizations and previous studies to focus on identifying an indicator which allows to predict and measure when a public entity could be dealing with financial difficulties [3,4,10].

In this regard, the concept of financial sustainability has become a key condition for public administrations because of its link to intergenerational equity or inter-period equity [13,29-32]. This concept goes further than other financial indicators of public administrations because it seeks to provide information about the coming financial years instead of trying to explain the current figures of the public sector $[10,33]$. So, it is centred on how a public entity can face its financial commitments and the same quantity and quality of its service delivery, avoiding an increase in the debt and compromising future generations $[4,27,30]$.

IFAC (2013) has determined that financial sustainability is composed of three dimensions: revenues, services, and debt. However, despite the discrepancy about the measurement of financial sustainability, International Organizations have stressed the usefulness of the governmental financial statements to assess financial sustainability $[3,29]$. Also, prior research has recognized the usefulness of government Income Statements for reporting the sustainability of public services $[6,34,35]$.

At this stage, it is important to distinguish between the concepts: budgetary expenditure/revenues which are part of the budget and provide the Annual Budget Results and financial expenditure/revenues which constitute the Income Statement. The differences between these concepts arise, on the one hand, from their content, and on the other, from the criteria applied for their allocation. Thus, some financial expenditures/revenues such as the consumption of capital investments, estimates of future costs and expenses incurred but pending allocation to the budget, among others, are not considered as budgetary expenditures/revenues. However, as these concepts effectively represent the organisation's capacity to maintain its financial well-being in the future, they should be considered in the measurement of financial sustainability.

Furthermore, in countries like Spain, while financial expenditures/revenues are allocated to the Income Statement in accordance with the accrual basis of financial accounting, the allocation of budgetary expenditures/revenues is primarily cash-based or follows a mixed cash-accrual criterion in determining the budget results. Therefore, considering that financial sustainability is based on intergenerational equity, it seems that it can be measured from a much more comprehensive standpoint using the Income Statement than budget information.

Also, the Income Statement [22] includes directly an approximate measure of revenues and services on an accrual basis and indirectly considers the debt dimension. So, this statement could provide useful information to measure the ability of public administrations to maintain the provision of public services keeping their quality, which is the principal characteristic of long-term financial sustainability $[4,31]$.

However, the information provided by the Income Statement needs to be broader in order to get useful information to make appropriated decisions regarding financial sustainability [4,24]. Specifically, there has been a growing worry about the sway of the demographic structure on public finances 
by International Organizations [3,4]. In fact, the UE has pointed out the significance of the current demographics changes for social policy, especially in the future [36], due to the uneven population growth between regions affects differently in the regional needs of providing services $[37,38]$. Therefore, the analysis of the socio-demographic factors has become essential to find out their effect on financial sustainability $[4,36,39]$.

Moreover, the study of these variables is also supported by two important theories: The Institutional Theory and the Stakeholders Theory.

The former theory explains that organisations respond to pressure from their environments, and adopt structures and practices that are considered legitimate and socially acceptable by other organisations in their field [40]. The basic premise of this theory is that organisations' tendency towards conformity with predominant norms, traditions and social influences in their external environments will lead to homogeneity among organisations in their structures and practices [41,42].

The latter theory is based on the understanding that a stakeholder is any group or individual who may affect or be affected by an organisation's efforts to achieve its goals [43]. Thus, the organizations should try to understand, respect, and meet the needs of all of those who have an interest in their goals $[43,44]$.

Therefore, considering these tow theories, the socio-demographic factors, especially the study of the population structure, becomes one of the external factors that most strongly affect public finances and thus, the financial sustainability. Firstly, because the presence of certain populations groups of population (dependent population, foreign population or unemployed people) could ask for specific public goods and services to meet their needs and, therefore, they could demand the implementation of public policies for their benefit (Stakeholder Theory) which affect the financial sustainability. Secondly, these population groups could demand greater information about the compliance with the LGs or RGs obligations comparing the measures taken with the most generally and socially accepted (Institutional Theory).

Under this background, the main explanatory socio-demographic factors studied in public finance research are population size, population density, dependency ratio, foreign people and unemployment rate $[4,36,45,46]$. In this research, we assess the influence of these factors through their relationship with the three dimensions of the financial sustainability proposed by the IFAC (revenues, expenditures, and debt).

According to prior research and the explained theories, the study of the population size become very important on public finances, since the population could be considered as the main stakeholder group which could increase its demand of public goods and services (Stakeholders Theory) and the financial sustainability of governments could be affected by the application of different social policies generally and socially accepted (Institutional Theory). Nevertheless, there is no consensus about the possible impact of population size on public finances. On the one hand, large governments tend to achieve higher financial sustainability due to greater economies of scale and scope [26]. However, population growth could increase the demand for public services and resources $[17,37,38]$. This fact involves higher expenditures but it does not always involve higher tax collection since an increase in public revenues does not depend only on the population growth, but also on the financial capacity of the population and of the economic activity. In fact, prior research has demonstrated that an increase in the population size could affect negatively on the financial sustainability of local governments in different countries [17]. As a result, the population size can have a negative effect on public spending [46] and on public debt [45], since an increase in the population brings an increase in the demand for resources and services [37].

Considering the theoretical background and owing to the influence of population size on expenditures and debt (two dimensions of the financial sustainability proposed by IFAC), the real effect of this variable on the financial sustainability at each governmental level should be carefully analysed. This comparison could be interesting to public managers and politicians because the result of this comparative analysis could help to find out if this variable influence regardless of the specific 
competences of each governmental level, or if each governmental level should establish different policies to try to control the effect of this variable. Therefore, we propose the following hypothesis:

Hypothesis 1 (H1) - The population size might affect financial sustainability in RG and LG.

Following the Stakeholders and Institutional Theories, the population density could be an important factor to analyse, since the pressure that can be exerted by stakeholders could be stronger with a greater population density, which could result in practices generally and socially accepted. However, in the same line, there is no consensus about the influence of the population density in public finances. In regions with higher concentration, the demand for public services and resources [38] could be higher, so this variable has been identified as a risk for public spending [46] have. However, an increase in the population density could benefit the economies of scale and reduce the expenditures per capita [26], i.e., higher population density causes lower spending and greater taxes per capita amounts [47]. On the other hand, the significant influence of this variable on the public debt has not been demonstrated [45]. In fact, there are previous studies that have not found any influence of the population density on the financial sustainability of local governments [17,48].

Therefore, making a comparative analysis of the influence of this variable could bring out its real effect on financial sustainability considering the governmental level, which could help politicians and public managers to take the appropriated decisions about financial sustainability in each governmental level. So, following prior research, as this variable could influence on the dimensions of the financial suitability (revenues, expenditures, and debt), its study would be interesting to discover its influence on financial sustainability taking into account the governmental level, thus, we consider this assumption:

Hypothesis 2 (H2) - The population density might influence the financial sustainability in RG and LG.

Apart from previous comments, the factor that most worries International Organisations $[3,49]$ is the dependent population (under 16 and over 65), which study also is supported by the Stakeholder and Institutional Theories. The elderly population (a stakeholder group) is growing faster than the rest and thus could influence the population balances $[29,36]$ affecting public finances and intergenerational equity. In fact, the society is very sensitized with the policies that affect this stakeholder group such as pensions or healthcare, thus, the measures adopted in favor of these groups could influence on the financial sustainability of different governmental institutions to be generally and socially accepted (Institutional Theory).

Moreover, some studies have brought out that dependent population is inversely associated with government revenue and directly associated with public expenditures, thus influence negatively on fiscal distress [50], on financial capacity [51] and on budget balance [46], since it influences on the pension payment pressure [12]. So, the dependent population affects two dimensions of financial sustainability (revenues and expenditures).

The comparative analysis of the dependent population between RGs and LGs could help to understand the effect of this variable on public finances since each governmental level has different competences regarding the dependent population. For this reason, we propose to analyse its influence on financial sustainability, considering separately two stakeholder groups, the dependent population under 16 and dependent population over 65, in order to discover how each stakeholder groups affects the financial sustainability of these two governmental levels. In fact, some authors have identified that the population under 16 is a riskier factor for financial sustainability of local governments than the population over 65 , due to the type of services that this level of government provides [10,17]. The results of this comparative analysis could help politicians and public managers of each governmental level to consider, which type of dependent population should be more monitored due to its influence on financial sustainability. Therefore, we hypothesize that: 
Hypothesis 3 (H3) - The dependent population under 16 could influence financial sustainability in RG and $L G$.

Hypothesis 4 (H4) - The dependent population over 65 could affect financial sustainability in RG and LG.

On the other hand, the foreign population is another variable whose effect on public finances needs more research studies, since they could be considered as another stakeholder group, which could influence in the public policies adopted by governments (Stakeholder and Institutional Theories). International organizations consider that immigration could help to maintain the population balance and soften the negative effect of the increase in the elderly population on public finances [36,52]. Moreover, the foreign population is related to an increase in the tax burden [53]. Hence, these foreign people could benefit the sustainability of the pension system and financial sustainability [36,52]. However, prior research has corroborated that, due to their tendency to increase the public expenditures $[15,46]$ and the accumulated debt $[45,53]$, migration flows influence negatively on the financial performance of public entities [51], and thus, on the financial sustainability, especially of local governments [10,17].

So, it seems that the contribution of the foreign population in the population balance, and thus in public revenues does not cover the public expenditures of the social services that they use. As prior research has found out, a different influence of the foreign population on the three dimensions of the financial sustainability, it may be worthwhile to clarify its specific effect on the financial sustainability for each public level. This could help to find out if the influence of this variable has a common influence on financial sustainability at each governmental level. This could mean that the influence of this variable could be a common characteristic of the different governments. So, we analyse the following hypothesis:

Hypothesis 5 (H5) - Foreign population could have an effect on financial sustainability in RG and LG.

Finally, the study of the effect of the unemployment rate (employed people stakeholder) on public finances becomes even more important, these days, due to its increase at international level in the crisis times. Indeed, despite having adopted different policies and measures, following the premises of the Stakeholders and Institutional Theories, all the countries at European level have suffered an increase of this variable regardless of their economic development or labour market stability [54], since its increase could provoke a decrease in the productivity and of public revenues $[27,51]$. This implies less collection of taxes (such as the Personal Income Taxes, Corporate Taxes, and other indirect taxes about the economic level of the population) which could jeopardize financial sustainability. Moreover, previous studies have confirmed its negative influence on social spending, due to the unemployment allowances. In addition, this situation could lead to increase the indebtedness [45]. Therefore, considering the theoretical background and due to its negative influence on the three dimensions proposed by IFAC (expenditure, revenues, debt), this factor is expected to have a negative effect on financial sustainability. However, due to the different competences of each governmental level on unemployment, it could be interesting to determine if the negative influence of this variable could straddle the governmental levels and become a common key variable for financial sustainability regardless of the governmental level. So, we consider hypothesizing that:

Hypothesis 6 (H6) - The unemployment rate could have an influence on financial sustainability in RG and LG.

\section{Research Methodology}

\subsection{Sample}

As indicated in previous sections, prior research has been mainly focused on the analysis of financial sustainability at the local governmental level. There are several reasons that could make prior 
research have been centred on LGs such as their closeness to citizens and the wide range of public services that they provide $[55,56]$.

Indeed, LGs are obliged to provide different services which are more specific and closer to citizens. The large LGs, those that we have considered in our study, provide the widest range of public services of LGs. Following the Local Government Regulatory Act 7/1985, amended by the Local Government Modernization Act 57/2003 (Article 25), they have competences on issues such as security and fire prevention and extinction, traffic management and conservation of public roads, urban development and housing promotion, social services, parks and gardens, water supply, street lighting, waste collection, public health protection and participation in the management of primary health care, cultural and sport services and environmental protection, and participate in teaching programming, among others.

However, RGs also have assumed important competences which oblige them to provide a wide range of more general public services. As the Spanish Constitution (Article 148) and the Autonomy Statutes of each RGs establish, RGs have competences on urban planning and housing, civil engineering, roads, railways, ports and sports airports, agriculture, livestock and forest, environmental protection, the promotion of culture, sports and tourism, social affairs, education, healthcare, and promotion of the economic development, among others.

These competences and services provided by these two levels make that LGs and RGs play a key role in promoting sustainable development as set out by previous research [57]. So, it seems interesting to analyze financial sustainability in both contexts.

In addition, the study of the financial sustainability and its influential factors comparing different levels of governments, concretely LGs and RGs, is particularly timely and relevant in countries like Spain, where the functions undertaken have provoked a duplication in the delivery of services by LGs and RGS and an expansion of the role of the public sector in economic activity [58] increasing the public revenues and expenditures. Moreover, it is interesting to highlight that, regarding the European sustainability indicators in the short, medium and long-term, Spain has suffered one of the highest gap [27]. This led the Spanish Government to take harsh economic measures for each governmental level, which aims at stabilizing the public finances (Law 2/2012, Stability and Financial Sustainability), such as deficit and expenditures targets. Under these new challenges, each governmental level has had a different result. In this sense, the local level is the only one that has met its objectives in recent years [28]. Therefore, while LGs had reached a budget balance, the RGs keep having a budgetary unbalance. In 2014, the aggregate deficit of the Spanish RGs was 1.75\% of Regional GDP and its accumulated debt was 368.9 millions of euros [59].

Following the above mentioned, we have collected data from LGs and RGs, in the period from 2006 to 2014. We have chosen this 9-year period because cover the period before, during and after the financial and economic crisis, i.e., it covers the boom and burst in the housing market since its peak in 2007 [60]. These make this study more comprehensive, showing it is timely and relevant.

Regarding LGs, consistent with prior research in local public finance $[45,48]$ we have chosen to examine solely LGs consider as large LGs. The Local Government Regulatory Act 7/1985, amended by the Local Government Modernization Act 57/2003 (Article 121), defined them as those with a population of over 50,000 inhabitants, together with those which, although smaller in terms of numbers, are classified as "large population" under of, i.e., municipalities that are provincial capitals, regional capitals or in which the headquarters of regional institutions are located. These municipalities account for more than $50 \%$ of the Spanish population [61,62]. Concretely, the 148 municipalities which meet these conditions represent $51.60 \%$ of the total population of Spain and disburse $11.18 \%$ of the total national budget. So, the demographic effects on LGs finance are apparent, and a broader range of stakeholders are involved [21,27]. Also, the information content of the financial statements of large LGs is expected to be more useful for measuring sustainability and more appropriate to be compared with the RGs because their accounting model is considerably more complete and detailed than the simplified version used by small ones. Moreover, as the Local Government Regulatory Act 7/1985 
establishes, the large LGs have more competences and greater available resources to provide more public services than small ones, which make them more comparable with the RGs. Finally, the Fiscal Sustainability Report concluded that the highest deficits in the LG sector were in large municipalities [3]. So, the implementation of economic development programs and the innovation regarding the measure of financial sustainability could be favoured in these ones [63].

Considering RGs, in Spain, there are 17 RGs and we have been able to obtain data from all of them. Therefore, our sample is composed of 17 RGs during the period 2006-2014.

\subsection{Variables}

As mentioned before, International Organizations $[4,27,30,31]$ and previous studies $[24,33]$ have recognized that the information reported by the income statement involves a direct approach of two dimensions of financial sustainability (revenues and services). Moreover, it reflects indirectly the debt dimension since it includes financial expenditure such as the interests and the link between the debt and the volume of expenditure.

However, as public income statements include extraordinary activities, the information provided could distort the assessment of the financial sustainability of public entities $[24,33]$ since the most probable is that these activities will not be repeated in a foreseeable future. So, as previous studies suggest $[6,9,17]$, the extraordinary revenues and expenditures should be corrected to make the income statement a more useful measure of the size of intergenerational equity, and thus, of the financial sustainability.

Therefore, following the recommendations of the main International Organizations $[3,4,64]$ and using the adjusted annual income statements, we have quantified the financial sustainability to maximize its utility as Table 1 shown.

Table 1. Dependent Variable. Financial Sustainability: Adjusted Income Statement.

\begin{tabular}{cc}
\hline Concept & Amount \\
\hline Income statement for the financial year obtained by applying the current IPSAS & $(1)$ \\
Negative entries for extraordinary activities & $(2)$ \\
Positive entries for extraordinary activities & $(3)$ \\
\hline Source: Own elaboration. & $(1)+(2)-(3)$ \\
\hline
\end{tabular}

The definition of the independent variables used as well as their measurement are collected in Table 2.

Table 2. Variables.

\begin{tabular}{|c|c|c|c|c|c|}
\hline Variables (Exp. Sing) & Acron. & Definition & Source & Calculation & $\mathbf{H}$ \\
\hline Financial Sustainability & FS & $\begin{array}{l}\text { Ability to continue current policy without } \\
\text { changes in public services and taxation and } \\
\text { without causing a continuously rising debt }\end{array}$ & $\begin{array}{l}\text { LG-RG } \\
\text { financial } \\
\text { statement }\end{array}$ & $\begin{array}{l}\text { Adjusted income statement } \\
\text { for the financial year per } \\
\text { capita }\end{array}$ & \\
\hline \multicolumn{6}{|c|}{ Independent variables } \\
\hline Population density $(-/+)$ & PD & Population residing in the $\mathrm{LG}-\mathrm{RG} / \mathrm{km}^{2}$ & INE & Population divided by $\mathrm{km}^{2}$ & $\mathrm{H} 2$ \\
\hline Dep. pop. 16 years $(-)$ & DP16 & Population aged $<16$ residing in LG-RG & INE & $\%$ Population aged under 16 & $\mathrm{H} 3$ \\
\hline Dep. pop. 65 years $(-)$ & DP65 & Population aged $>65$ residing in LG-RG & INE & \% Population aged over 65 & $\mathrm{H} 4$ \\
\hline Foreign pop. $(-/+)$ & FP & Foreign population residing in LG-RG & INE & $\%$ foreign population & H5 \\
\hline Unemployment rate $(-)$ & UR & Unemployment rate in the LG-RG & $\mathrm{SEPE}^{2}$ & $\%$ Unemployed population & H6 \\
\hline
\end{tabular}

Source: Own elaboration; Note: (1) INE: Statistic Institute of Spain (www.ine.es); (2) Public Employment Service of Spain (www.sepe.es). 


\subsection{Methodology}

To achieve the aim of our study, we collected the dependent and independent variables for 148 LGs and 17 RGs over a 9-years period (2006-2014), which cover the period before, during and after the boom and burst in the housing market [60] as several previous studies show [5,17]. Although we have been able to collect all the data regarding the RGs, we could have obtained the data only of 138 LGs.

Therefore, according to the aim of this study and our data sample, we used a panel data technique, the most frequent technique used in public finances $[65,66]$, to identify the driving and/or risk factors that could impact on the financial sustainability of each governmental level. This technique increases the number of observations that can be considered by pooling different time-series [65] and enables us to detect the unobservable and constant heterogeneity. Moreover, it reduces multicollinearity and improves the efficiency of the model [67].

We have analysed two models, the first one to identify the driving and risk factor of the financial sustainability of LGs, i.e., we have a vector of variables for $138 \mathrm{LGs}(\mathrm{N})$ over 9-years periods of time ( $\mathrm{T}=$ from 2006 to 2014), and the second one to discover the driving and risk factor of the financial sustainability of RGs, composed of a vector of variables for 17 RGs (N) over 9-years periods of time ( $\mathrm{T}=$ from 2006 to 2014). So, we have tested the following equation models:

$$
\begin{gathered}
\mathrm{FS}_{\mathrm{it}}=\alpha+\beta_{1} \mathrm{LNPO}_{\mathrm{it}}+\beta_{2} \mathrm{PD}_{\mathrm{t}}+\beta_{3} \mathrm{DP} 16_{\mathrm{it}}+\beta_{4} \mathrm{DP} 65_{\mathrm{it}}+\beta_{5} \mathrm{FP}_{\mathrm{it}}+\beta_{6} \mathrm{UR}_{\mathrm{it}}+\mathrm{u}_{\mathrm{i}} \\
\mathrm{FS}_{\mathrm{kt}}=\alpha+\beta_{1} \mathrm{LNPO}_{\mathrm{kt}}+\beta_{2} \mathrm{PD}_{\mathrm{t}}+\beta_{3} \mathrm{DP} 16_{\mathrm{kt}}+\beta_{4} \mathrm{DP} 65_{\mathrm{kt}}+\beta_{5} \mathrm{FP}_{\mathrm{kt}}+\beta_{6} \mathrm{UR}_{\mathrm{kt}}+\mathrm{u}_{\mathrm{k}}
\end{gathered}
$$

where " $\mathrm{i}$ " and " $\mathrm{k}$ " are the $\mathrm{i}$-th/$/ \mathrm{k}$-th transversal units (LGs and RGs, respectively) and " $\mathrm{t}$ " is the time (year).

In this technique, the error $\left(\mathrm{u}_{\mathrm{it}} / \mathrm{u}_{\mathrm{kt}}\right)$ is divided into the error term $\left(\mathrm{e}_{\mathrm{i}} / \mathrm{e}_{\mathrm{k}}\right)$ and the unobservable heterogeneity $\left(\alpha_{\mathrm{i}} / \alpha_{\mathrm{k}}\right)$. This unobservable heterogeneity $\left(\alpha_{\mathrm{i}} / \alpha_{\mathrm{k}}\right)$ is the key element of the panel date since it is a local/regional specific constant term designed to measure the unobservable characteristics of the LGs and RGs that have a relevant effect on financial sustainability. The error term $\left(\mathrm{e}_{\mathrm{i}} / \mathrm{e}_{\mathrm{k}}\right)$ is a stochastic residual capturing unexplained intra-local/regional government differences in financial sustainability, and $\alpha$ and $\beta$ are coefficients to be estimated.

In addition, when there are variables that could influence the country development and could have a dependent trajectory that describes a cumulative process [68] it is essential to take into consideration the possible existence of endogeneity [69].

On account of that, we used the by System-Generalized Method of Moment (GMM) to estimate these models [70,71]. Indeed, this is the most powerful estimation to control the possible endogeneity between the endogenous variables and the error term [69], since it uses the lagged levels of the endogenous regressors as instrumental variables [67]. Moreover, it improves the efficiency of the models combining the moment conditions for the equations in first-differences with additional moment conditions implied for equations in level [71]. Furthermore, in order to overcome the bias due to the incomplete (LGs) and the small sample (RGs), we have used the two-step estimation and the Windmeijer's correction $[72,73]$ with the aim at making these models asymptotically more efficient and robust for any patterns of heteroskedasticity and cross-correlation [72,74].

Finally, we have validated the robustness of our findings performing the Arellano-Bond test (m) to check the inexistence of serial correlation [75] and the Hansen test to verify the adequacy of the instruments used to control the endogeneity [76] (Table 3).

So, we have obtained robust results that allow us to properly support the findings related to the purpose of the paper, controlling for any type of endogeneity and multicollinearity that may exist between the variables. 
Table 3. Hypothesis Testing.

\begin{tabular}{cccc}
\hline Test & & Local Governments & Regional Governments \\
\hline Arellano test (1) & $\mathrm{z}$ & -6.53 & -3.32 \\
& $\operatorname{Pr}$ & 0.002 & 0.001 \\
Arellano test (2) & $\mathrm{z}$ & -0.03 & 0.15 \\
& $\mathrm{Pr}$ & 0.973 & 0.882 \\
Hansen test & $\mathrm{chi}$ & 46.321 & 41.23 \\
& $\mathrm{Pr}$ & 0.228 & 0.417 \\
\hline
\end{tabular}

Source: Stata 12.

\section{Results}

\subsection{Statistical Analysis}

Beginning with our dependent variable (the measurement of financial sustainability), a huge difference between these two levels of governments (Table 4) could be observed. While the mean of the LGs' financial sustainability is positive, the mean of RGs' financial sustainability is negative. Therefore, it could be considered that LGs have managed financial sustainability more successfully than RGs during the studied period. These results are consistent with the recent reports about the achievement of the financial objectives in LGs and RGs proposed by the central government in Spain [28]. Following this report, only LGs reached their target of debt, deficit, and expenditures, while RGs are still having a deficit. On the other hand, this variable is the only one which behaviour among LGs and RGs (between) is more homogeneous than in each LG or RG along years (within). Therefore, it can be considered that the financial and economic crisis provoked that the behavior of the financial sustainability had a common turning point similar to all LGs and RG, although LGs managed their negative effects better (Table 4).

Table 4. Descriptive Statistics.

\begin{tabular}{|c|c|c|c|c|c|c|c|c|c|}
\hline \multirow{2}{*}{\multicolumn{2}{|c|}{ Variable }} & \multicolumn{4}{|c|}{ Local Governments } & \multicolumn{4}{|c|}{ Regional Governments } \\
\hline & & \multirow{3}{*}{$\begin{array}{c}\text { Mean } \\
96.1208\end{array}$} & \multirow{3}{*}{$\begin{array}{c}\begin{array}{c}\text { Std. } \\
\text { Dev. }\end{array} \\
181.9269 \\
95.9308 \\
156.6037\end{array}$} & \multirow{3}{*}{$\begin{array}{c}\text { Min } \\
-748.5146 \\
-258.1706 \\
-592.9241\end{array}$} & \multirow{3}{*}{$\begin{array}{c}\text { Max } \\
2177.629 \\
373.9224 \\
1899.827\end{array}$} & \multirow{3}{*}{$\begin{array}{c}\text { Mean } \\
-49.1687\end{array}$} & \multirow{3}{*}{$\begin{array}{c}\begin{array}{c}\text { Std. } \\
\text { Dev. }\end{array} \\
438.6733 \\
245.902 \\
367.6261\end{array}$} & \multirow{3}{*}{$\begin{array}{c}\text { Min } \\
-1555.205 \\
-517.9441 \\
-1086.43\end{array}$} & \multirow{3}{*}{$\begin{array}{c}\text { Max } \\
1109.125 \\
320.5749 \\
739.381\end{array}$} \\
\hline $\begin{array}{l}\text { Financial } \\
\text { sustainability }\end{array}$ & between & & & & & & & & \\
\hline & within & & & & & & & & \\
\hline \multirow{2}{*}{ Population } & overall & & 0.7369 & 10.4244 & 15.0012 & \multirow{2}{*}{14.43485} & 0.8984 & 12.6325 & 15.9496 \\
\hline & within & & 0.0373 & 11.3401 & 11.7578 & & 0.0208 & 14.3561 & 14.4679 \\
\hline \multirow{3}{*}{$\begin{array}{l}\text { Population } \\
\text { Density }\end{array}$} & overall & & 3093.868 & 51.5531 & $18,474.43$ & \multirow{3}{*}{159.8013} & 183.1589 & 15.7625 & 809.486 \\
\hline & between & 2326.146 & 3102.627 & 53.5232 & $18,175.84$ & & 188.0695 & 16.3876 & 790.917 \\
\hline & within & & 88.1826 & 1530.875 & 2904.835 & & 6.2145 & 117.2874 & 178.370 \\
\hline $\begin{array}{l}\text { Dependent } \\
\text { population } \\
\text { under } 16\end{array}$ & overall & & 3.3564 & 15.4426 & 33.6056 & 22.81048 & 2.7042 & 16.0173 & 28.2661 \\
\hline \multirow{2}{*}{$\begin{array}{l}\text { Dependent } \\
\text { population } \\
\text { over } 65\end{array}$} & between & 21.8223 & 6.3508 & 6.0774 & 36.7378 & \multirow[t]{2}{*}{26.76682} & 5.0067 & 18.8053 & 35.3392 \\
\hline & within & & 1.699 & 15.5009 & 29.05174 & & 1.1489 & 24.5610 & 29.9692 \\
\hline \multirow{3}{*}{$\begin{array}{c}\text { Foreign } \\
\text { population }\end{array}$} & overall & & 9.5200 & 0.9415 & 53.5425 & \multirow{3}{*}{10.0813} & 4.9008 & 2.3366 & 20.9441 \\
\hline & between & 12.8916 & 9.4572 & 1.2197 & 51.6375 & & 4.9449 & 3.1915 & 19.5274 \\
\hline & within & & 1.3294 & 4.9365 & 16.6981 & & 0.92 & 7.0798 & 11.4980 \\
\hline \multirow{3}{*}{$\begin{array}{l}\text { Unemployment } \\
\text { rate }\end{array}$} & overall & & 4.9825 & 3.1200 & 27.3782 & \multirow{3}{*}{17.17327} & 8.0691 & 5.13 & 36.77 \\
\hline & between & 12.3887 & 3.1236 & 5.0018 & 21.1375 & & 4.3123 & 11.3955 & 25.0644 \\
\hline & within & & 3.8899 & 3.3400 & 20.2759 & & 6.8915 & 3.3177 & 29.1688 \\
\hline
\end{tabular}

Local Government: $\mathrm{N}=1242 ; \mathrm{n}=138 ; \mathrm{T}=9$. Balanced panel; Regional Government: $\mathrm{N}=153 ; \mathrm{n}=17 ; \mathrm{T}=9$. Unbalanced panel. 
Regarding the independent variables, the population density is the variable that has the highest standard deviation and is the most different between LGs and RGs. So, in general, LGs seem to be more populated than RGs. Analyzing the dependent population, while RGs have a more raised level of the dependent population over 65 (26.76\% in RGs and $21.8 \%$ in LGs), LGs have a higher rate of the dependent population under 16 (23.89\% in LGs and $22.81 \%$ in RGs). Moreover, there is more foreign population in LGs $(12.89 \%)$ than in RGs $(10.08 \%)$, which could mean that foreign population tends to be concentrated in LGs with relatively large populations which are those considered in our study. Finally, the unemployment rate is significantly higher and more heterogeneous in RGs $(17.17 \%)$ than in LGs $(12.39 \%)$.

Therefore, the social-demographic structure of LGs is considerably different from the social-demographic structure of RGs. This fact could make that the influence on each variable has a different effect on the financial sustainability of each governmental level.

\subsection{Analysis of Results}

We have been able to identify socio-demographic factors which could be driving or risk factors for the financial sustainability of these public entities (Table 5). In fact, our results allow us to realize that, between the socio-demographic factors that have been analysed in this study, it can be differentiated into three groups (Table 5).

Table 5. The model.

\begin{tabular}{ccccc}
\hline & \multicolumn{2}{c}{ Local Governments } & \multicolumn{2}{c}{$\begin{array}{c}\text { Regional } \\
\text { Governments }\end{array}$} \\
\hline Financial sustainability lagged one period & 0.1693 & $* * *$ & 0.2086 & $* * *$ \\
Population & -132.4505 & $* *$ & -12398.8 & $* *$ \\
Population Density & 0.0111 & & 12.7726 & $* * *$ \\
Dependent population under 16 & -7.2512 & $* *$ & 40.0704 & $*$ \\
Dependent population over 65 & -1.0822 & & -117.5854 & $* * *$ \\
Foreign population & -6.2275 & $* *$ & -112.1973 & $* * *$ \\
Unemployment rate & -9.0988 & $* * *$ & -15.0761 & $*$ \\
Constant & 2026.21 & $* *$ & 180631.7 & $*$ \\
\hline
\end{tabular}

Source: Own elaboration based on the test performed in STATA12; Note: (1) GMM-Dynamic Panel data-Two Step;

(2) Fixed effect of time considered; (3) We used the option collapse to reduce the instruments of the model [72];

(4) Stata 12: * P-value $<0.10,{ }^{* *} \mathrm{P}$-value $<0.05,{ }^{* * *} \mathrm{P}$-value $<0.01$.

First, we have been able to confirm that for both governmental levels (Spanish LGs and RGs), the financial sustainability of the previous year has a positive effect on the financial sustainability of the current year (Spanish LGs and RGs) (Table 5).

In addition, our findings have demonstrated that there are socio-demographic factors that could have an effect on the financial sustainability of both governmental levels, LGs and RGs, such as population size and foreign population (Table 5).

So, we can confirm and accept the H.1 and the H.5, i.e., the population size and the foreign population have a negatively effect on financial sustainability in RG and LG.

These results are in concordance with the theoretical framework and the prior studies which found that an increase in the population size provokes an increase in the demand for services $[17,37,38]$, and thus, in public spending [46], and in public debt [45].

Moreover, our results extend previous studies since we have discovered that the foreign population not only affects negatively on financial performance [51], public expenditures $[15,46]$ and debt $[45,53]$ but also on the financial sustainability of both, LGs and RGs.

Therefore, we found that an increase in the population or/and in the foreign population could be considered as risk factors since it can damage not only the LGs' financial sustainability but also the RGs' one. In this sense, we could demonstrate that these two stakeholder groups have the power to influence the financial sustainability of both governmental levels, which also imply that the measures 
in favor of these two groups could become generally and socially accepted and, thus, they could be considered in any level of government.

Second, our results reveal that there are socio-demographic factors which could be risk factors for only the financial sustainability of LGs (unemployment rate and population under 16) (Table 5).

Therefore, the H.3 and H.6 could be only accepted by the Local Governments, since the population aged under 16 and unemployment rate only affect negatively on Local Governments, but it seems not to have any influence on Regional ones. Following the theoretical framework, these two groups of stakeholders could exert greater pressure in LGs.

Regarding the unemployment rate, our results, through this comparative analysis, go further than prior research which identified a negative effect of the unemployment rate on productivity, revenues, expenditures, and debt $[27,45]$. Thus, we can identify that the unemployment rate is a risk factor only for financial sustainability of LGs. To deepen in the results of this variable could have been interesting to divide this variable according to the activity sector, and analyse the different impact that could have the unemployment rate of each sector in the financial sustainability of LGs and RGs. However, the unemployment rate with this level of detail was not available for the whole sample, so this represents a limitation on our analysis.

Moreover, our results show that whereas the population under 16 affects negatively on the financial sustainability of LGs, the population over 65 has a negative influence on the financial sustainability of RGs (Table 5). Therefore, our results confirm the influence of these stakeholder groups following the Stakeholder and Institutional Theories and the worry about the dependent population (under 16 and over 65) for public finances, since this population affect the population balance [29,36] jeopardizing the fiscal distress [50], the financial capacity [51], the budget balance [46], and thus, the financial sustainability. In addition, these results are in the same line than prior research which found that the population aged under 16 has a higher impact on the financial sustainability of local governments than the elderly population $[10,17]$.

This comparative analysis goes further than prior research since it develops that the influence of each type of dependent population depends on the governmental level and their competences about services delivered to this population.

Third, our results disclose some potential driving and risk socio-demographic factors which affect only on the financial sustainability of RGs such as the dependent population over 65, above mentioned, and the population density (Table 5). In this case, and considering the theoretical framework, while the dependent population over 65 considered as a group of stakeholders could exert greater pressure in Regional Governments, we have been able to identify that the population density could not be related to the pressure that could exert the stakeholders, since it has been considered as a driver for the financial sustainability of RGs.

Therefore, the H.2 could be only accepted by the Regional Governments, because while the population density only affects positively on Regional Governments, there no signal of their influence on Local Governments. In parallel, as the population over 65 has no influence on the financial sustainability of Local Governments, the H.4 only could be accepted by the Regional Governments, where its influence is negative.

Analysing the population density, while this factor is a driver for RGs' financial sustainability, LGs' financial sustainability seems not to be affected by it, according to prior research on debt [45]. This fact could be based on the economies of scale and the possible reduction of the expenditures per capita, as Andrews (2015) suggested. Hence, our results reveal not only the positive effect on financial sustainability in RGs but also that the influence of this variable on financial sustainability depends on the governmental level and their competences.

\section{Discussion}

Using panel data composed by LGs and RGs during the period 2006-2014, this study contributes to previous research with important and appropriate finding in the comparison of the potential driving 
and risk socio-demographic factors for the financial sustainability of two governmental levels, LGs and RGs.

Considering the theoretical framework based on the two major theories: The Stakeholders Theory and the Institutional Theory and focusing on the potential socio-demographic factors that affect the financial sustainability of both governmental levels, LGs and RGs, our results identified the population size and the foreign population as risk factors. That means that the population size and the foreign population, despite helping to mitigate the negative impact of the increase of the elderly population [36,52], seem to influence negatively on the financial sustainability regardless of the governmental level or competences. So, they are key factors (Stakeholders Theory) for Spanish entities that should be considered to establish the different sustainable policies at any governmental level (Institutional Theory) with the aim at reaching a joint and global sustainable development. These findings allow us to empirically verify the usefulness of these two theories to identify explanatory variables of financial sustainability at the two levels of governments studied.

Furthermore, our results reveal the positive effect of the previous year financial sustainability of LGs and RGs which could have a twofold meaning. On the one hand, if the financial sustainability of the previous year was positive, the expectations are to maintain or to improve the financial sustainability for the following year. However, if the financial sustainability of the previous year was negative, it could be more difficult to recover a positive financial sustainability the following year.

On the other hand, regardless of the impossibility of analysing the unemployment rate for each economic sector, our findings have demonstrated that the unemployment rate and dependent population under 16 could be considered as risk factors (Stakeholders Theory) only for the financial sustainability of LGs. The employed people use the services provided by LGs which are the closest to citizen (such as street lighting, waste collection, public parks, cultural services and environmental protection). However, these unemployed people, as well as the dependent population, can fail to finance collectively the public services they receive from LGs. Therefore, the proximity of the citizen to the government can condition the influence of these variables on financial sustainability.

Although RGs provide unemployed people with some specific services such as the access to offers of employment, training courses or social services, the cost of these services is lower than the services provided by LGs. For instance, the facilities and the staff needed in the provision of this type of services are less in comparison with the infrastructure and the public employees that are necessary to maintain all the public services provided by the LGs. That could be the reason why the employed people affect negatively only in LGs. Therefore, LGs particularly should take care of these group of population (Stakeholders Theory) establishing different policies (Institutional Theory) that help to counteract its negative effect on the financial sustainability which allow LGs to promote sustainable development (Institutional Theory).

Regarding the dependent population, it has a different influence. While the dependent population under 16 (Stakeholders Theory) affect negatively on LGs financial sustainability, dependent population over 65 (Stakeholders Theory) influence negatively on RGs financial sustainability. This difference is perhaps produced by the types of services that each level of government provides (Institutional Theory). LGs are responsible for providing services which could be more used by youth population such as the participation in monitoring the compulsory schooling and the promotion of parks and public gardens, of sports and leisure facilities, and of culture and cultural facilities. In this regard, following the data provided in the Ministry of Finance and Public Administration website, LGs dedicate around the 13\% of their budgets to services such as education, culture and sport which are more demanding for youth people, while approximately the $7 \%$ of their budgets are associated with the Social Healthcare and Social Protection and Social Safety (Institutional Theory). This corroborates that the expenditure of LGs for the youth population is usually greater than for the elderly population. So, it could be reasonable that the dependent population under 16 affects negatively on LGs public finances while there is an insignificant influence of the dependent population over 65. 
On the other hand, although the RGs are responsible for providing mandatory education, their other two main competences are social assistance and health care, which are probably more used by elderly people. Indeed, approximately the $35 \%$ and $10 \%$ of the RGs budget (excluding EAGF funds and Local Financial Intermediation) are dedicated to the Social Healthcare and Social Protection and Social Safety, respectively [59]. Moreover, The Educational Service requires $20 \%$ of the RGs budget (excluding EAGF funds and Local Financial Intermediation) (Institutional Theory) [59].

So, considering these figures, we can consider that the RGs spend more on the elderly population than on youth population and for this reason, the dependent population over 65 affects negatively on RGs public finances while there is an insignificant influence of the dependent population under 16.

Therefore, it is interesting to highlight that while LGs sustainable policies should centre their attention on people under 16 (Institutional Theory), the RGs sustainable policies should worry about the population over 65 (Institutional Theory). It is essential to consider that the policies established by each governmental level in order to counteract the negative effect of the dependent population should be different.

Finally, our findings have identified that the population density is a driver only for RGs' financial sustainability. In this regard, it seems that this variable is more heterogeneous in LGs than in RGs. That means that there are LGs with a high population density and municipalities with a low population density but all of them have to provide the same services to citizens. The possible benefit of the most populous municipalities could be compensated with the effort that the less populous municipalities have to make to provide the same services to citizens.

However, it can be observed that in RGs the fact of being more populous has a positive effect on financial sustainability. So, taking into account that the population density in RGs is more homogeneous, RGs could take higher advantages of the economies of scale and reduce the expenditures per capita, in line with Andrews (2015), since those which have to provide the same public services have approximately the same population density. Therefore, the impact of these benefits could be clearest and more significant in RGs than in LGs. So, RGs should establish policies that take advantages of this driving factor in order to promote sustainable development.

\section{Conclusions}

Under the framework of the financial and economic crisis, which has led to large public budget gaps and an increase of public debt levels [39], the discussions and the analysis of the public financial sustainability has turned into a relevant issue more important than other dimensions of the sustainability (social or environmental) [8,9,77] in all levels of governments [39]. However, some previous research has centred the study of financial sustainability in LGs, leaving aside other crucial levels of governments such as RGs.

By contrast, this study has analysed and identified the risk factor and drivers that could affect differently on LGs and RGs through a comparative analysis study. This research tries to discover whether the influential factors for financial sustainability depend on the competences of each governmental level or affect financial sustainability regardless of the level of the public administration.

Regarding the drivers and risk factors analysis, our findings indicate that socio-demographic elements, such as population size and the foreign population can be considered as risk factors for financial sustainability regardless of the level of government and competences. However, there are specific variables that only influence financial sustainability depending on the specific characteristic and competences of each governmental level such as the dependent population, the population density and the unemployment rate.

In parallel, the identification of the explanatory variables has allowed us to empirically test the usefulness and consistency of the Stakeholders Theory and the Institutional Theory to know the conditions of the sustainable behavior of governments. In addition, our results reveal that the citizen's proximity to the government can affect this behavior of governments. 
These findings represent a remarkable advance on the conclusions of the previous research since they confirm International Organizations assertions about the influence of demographic variables on financial sustainability $[3,4,27]$. This way, the current demographics changes are new challenges for social policies which likely become even more important in the future [36]. The demographic variables such as the population size and the dependent population (under 16 and over 65) are expected to be variables beyond the control of the government, therefore, politicians and public managers should take actions accordingly to the influence of these variables in each level of government in order to become financially sustainable. So, future research could be focused on how to face the demographic factor in each level of government and to foster employment with strategies that consider the demographic structure.

In conclusion, although financial sustainability is a vigorous debate nowadays in the public area, few studies have been focused on a comparative analysis of drivers and/or risk factors that could explain this issue in different levels of government. Our study confirms that demographic variables are ones of the most worrying factors for the financial sustainability of public entities regardless of the level of government.

The models of funding public administration, the management of the public administration and the public policies established should consider the demographic factors. The information about the evolution and the effect of the demographic factors in each level of government could help to adopt the most appropriated policies with the aim at achieving financial sustainability in all levels of government.

Author Contributions: Conceptualization, M.P.R.B., A.N.G., L.A.M. and M.D.L.S.; methodology, M.P.R.B. and A.N.G.; validation A.N.G. and L.A.M.; formal analysis, L.A.M. and M.D.L.S; investigation, M.D.L.S. and M.P.R.B., writing-original draft preparation, M.D.L.S., M.P.R.B., L.A.M., and A.N.G.; writing—review and editing, L.A.M. and M.D.L.S.; supervision, A.N.G. and M.P.R.B.

Funding: This research received no external funding.

Conflicts of Interest: The authors declare no conflict of interest.

\section{References}

1. Méndez, R.; Abad, L.D.; Echaves, C. Atlas de la crisis. Impactos Socioeconómicos y Territorios Vulnerables en España; Tiranch Lo Blanch, Colección Crónica: Valencia, Spain, 2015.

2. García-Sánchez, I.M.; Frías-Aceituno, J.V.; Rodríguez-Domínguez, L. Determinants of corporate social disclosure in Spanish local governments. J. Clean. Prod. 2013, 39, 60-72. [CrossRef]

3. EU. Fiscal Sustainability Report; European Union: Luxembourg, 2016; ISBN 9789279228568.

4. IFAC Recommended Practice Guideline. Reporting on the Long-Term Sustainability of an Entity's Finances; IFAC: Toronto, ON, Canada, 2013.

5. Navarro-Galera, A.; Rodríguez-Bolívar, M.P.; Alcaide-Muñoz, L.; López-Subires, M.D. Measuring the financial sustainability and its influential factors in local governments. Appl. Econ. 2016, 48, 1-15. [CrossRef]

6. Rodríguez-Bolívar, M.P.; Navarro-Galera, A.; López-Subirés, M.D.; Alcaide-Muñoz, L. Analysing the accounting measurement of financial sustainability in local governments through political factors. Account. Audit. Account. J. 2018, 31, 2135-2164. [CrossRef]

7. GRI. G4 Sustainability Reporting Guidelines; Global Reporting Initiative (GRI): Amsterdam, The Netherlands, 2015.

8. Afonso, A.; Jalles, J.T. Fiscal sustainability: A panel assessment for advanced economies. Appl. Econ. Lett. 2015, 22, 925-929. [CrossRef]

9. Rodríguez, M.P.; Navarro, A.; Alcaide, L. New development: The role of accounting in assessing local government sustainability. Public Money Manag. 2014, 34, 233-236.

10. Rodríguez, M.P.; Navarro, A.; Alcaide, L.; López, M.D. Analyzing Forces to the Financial Contribution of Local Governments to Sustainable Development. Sustainability 2016, 8, 925. [CrossRef]

11. Haider, S.; Bao, G.; Larsen, G.L.; Draz, M.U. Harnessing sustainable motivation: A grounded theory exploration of public service motivation in local governments of the state of Oregon, United States. Sustainability 2019, 11, 3105. [CrossRef]

12. Chen, X.; Yang, Z. Stochastically Assessing the Financial Sustainability of Individual Accounts in the Urban Enterprise Employees' Pension Plan in China. Sustainability 2019, 11, 3568. [CrossRef] 
13. CICA. Public sectOr Statements of Recommended Practice (SORP) 4.Indicators of Financial Condition; CICA: Toronto, ON, Canada, 2009.

14. IFAC. Handbook of International Public Sector Accounting Pronouncements; IFAC: New York, NY, USA, 2014; ISBN 9781608151196.

15. Chapman, J.I. State and Local Fiscal Sustainability: The Challenges. Public Adm. Rev. 2008, 68. [CrossRef]

16. Lein, J. Toward a Remote Sensing Solution for Regional Sustainability Assessment and Monitoring. Sustainability 2014, 6, 2067-2086. [CrossRef]

17. Rodríguez Bolívar, M.P.; López Subires, M.D.; Alcaide Muñoz, L.; Navarro Galera, A. The financial sustainability of local authorities in England and Spain: A comparative empirical study. Int. Rev. Adm. Sci. 2019. [CrossRef]

18. Lee, M.; Hwang, I.T. The effect of the compensation system on earnings management and sustainability: Evidence from Korea banks. Sustainability 2019, 11, 3165. [CrossRef]

19. Benito, B.; Brusca, I.; Montesinos, V. The harmonization of government financial information systems: The role of the IPSASs. Int. Rev. Adm. Sci. 2007, 73, 293-317. [CrossRef]

20. Bisogno, M.; Cuadrado-Ballesteros, B.; García-Sánchez, I.M. Financial sustainability in local governments: Definition, measurement and determinants. Financ. Sustain. Public Adm. Explor. Concept Financ. Heal. 2017, 57-83.

21. EU. Fiscal Sustainability Report; European Union: Brussels, Belgium, 2015.

22. IFAC. Handbook of International Public Sector Accounting Pronouncements; IFAC: New York, NY, USA, 2016.

23. EU. Fiscal Sustainability Report; European Union: Brussels, Belgium, 2012.

24. Williams, B.; Wilmshurst, T.; Clift, R. The Role Of Accountants In Sustainability Reporting-A Local Government Study. In Proceedings of the Sixth Asia Pacific Interdisciplinary Research in Accounting Conference, University of Sydney, Sydney, Australia, 12-13 July 2010; pp. 1-18.

25. Rodríguez, M.P.; Navarro, A.; Alcaide, L.; López, M.D. Factors Influencing Local Government Financial Sustainability: An Empirical Study. Lex Localis 2014, 12, 31-54. [CrossRef]

26. Andrews, R. Vertical consolidation and financial sustainability: Evidence from English local government. Environ. Plan. C Gov. Policy 2015, 33, 1518-1545. [CrossRef]

27. EU. Stability and Growth Pact; European Union: Strasbourg, France, 2012.

28. Ministry of Finance and Public Administration. Report on the Compliance of the Objective of Budget Stability, and Public Debt and the Rule of Expenditures of FY2014; Ministry of Finance and Public Administration: Madrid, Spain, 2014.

29. IFAC. Reporting on the Long-Term Sustainability of a Public Sector Entity's Finances; IFAC: New York, NY, USA, 2011.

30. EC. Council Directive 2011/85/EU of 8th November 2011 on Requirements for Budgetary Frameworks of the Member States; EC: Brussels, Belgium, 2011.

31. GASB. Why Governmental Accounting and Financial Reporting is-and Should be-Different; GASB: Norwalk, CT, USA, 2013.

32. Zafra-Gómez, J.L.; López-Hernández, A.M.; Hernández-Bastida, A. Developing an alert system for local governments in financial crisis. Public Money Manag. 2009, 29, 175-181. [CrossRef]

33. López, M.D.; Rodríguez, M.P. Financial Sustainability in Governments. A New Concept and Measure for Meeting New Information Needs. In Financial Sustainability in Public Administration: Exploring the Concept of Financial Health; Rodríguez Bolívar, M.P., Ed.; Springer International Publishing: Cham, Germany, 2017; pp. 3-20, ISBN 978-3-319-57962-7.

34. Bracci, E.; Humphrey, C.; Moll, J.; Steccolini, I. Public sector accounting, accountability and austerity: More than balancing the books? Account. Audit. Account. J. 2015, 28, 878-908. [CrossRef]

35. Heald, D.; Hodges, R. Will "austerity" be a critical juncture in european public sector financial reporting? Account. Audit. Account. J. 2015, 28, 993-1015. [CrossRef]

36. Eurostat. Sustainable Development in the European Union; Publications Office of the European Union: Luxembourg, 2015; ISBN 978-92-79-31155-0.

37. Balatsky, A.; Balatsky, G.; Borysov, S. Resource Demand Growth and Sustainability Due to Increased World Consumption. Sustainability 2015, 7, 3430-3440. [CrossRef]

38. Conard, B. Some Challenges to Sustainability. Sustainability 2013, 5, 3368-3381. [CrossRef]

39. EC. Council Recommendation on the 2016 national Reform Programme of Spain; EC: Brussels, Belgium, 2016. 
40. Ribeiro, J.A.; Scapens, R.W. Institutional theories in management accounting change. Qual. Res. Account. Manag. 2006, 3, 94-111. [CrossRef]

41. Powell, W.W.; DiMaggio, P.J. The New Institutionalism in Organizational Analysis; University of Chicago Press: Chicago, IL, USA, 1991; ISBN 022618594X.

42. Coase, R.H. The New Institutional Economics. J. Inst. Theor. Econ. 1984, 229-231.

43. Freeman, R.E. Strategic Management: A Stakeholder Approach; Pitman: Boston, MA, USA, 1984.

44. Donaldson, L. The Contingency Theory of Organizations; Sage: New York, NY, USA, 2001; ISBN 0761915745.

45. Guillamón, M.D.; Benito, B.; Bastida, F. Evaluación de la deuda pública local en España. Rev. Española Financ. Contab. 2011, XL, 251-285.

46. Choi, S.O.; Bae, S.-S.; Kwon, S.-W.; Feiock, R. County Limits: Policy Types and Expenditure Priorities. Am. Rev. Public Adm. 2010, 40, 29-45. [CrossRef]

47. Bastida, F.; Benito, B.; Guillamón, M.D. An Empirical Assessment of the Municipal Financial Situation in Spain. Int. Public Manag. J. 2009, 12, 484-499. [CrossRef]

48. Rodríguez, M.P.; Navarro, A.; Alcaide, L.; López, M.D. Risk Factors and Drivers of Financial Sustainability in Local Government: An Empirical Study. Local Gov. Stud. 2016, 42, 29-51. [CrossRef]

49. EC. Sustainability Report 2009; European Economy series; European Commission: Luxembourg, 2009.

50. Kloha, P.; Weissert, C.S.; Kleine, R. Developing and Testing a Composite Model to Predict Local Fiscal Distress. Public Adm. Rev. 2005, 65, 313-323. [CrossRef]

51. Zafra-Gómez, J.L.; López-Hernández, A.M.; Hernandez-Bastida, A. Developing a Model to Measure Financial Condition in Local Government: Evaluating Service Quality and Minimizing the Effects of the Socioeconomic Environment: An Application to Spanish Municipalities. Am. Rev. Public Adm. 2009, 39, 425-449. [CrossRef]

52. Eurostat Migration and Migrant Population Statistics. Eurostat, Statistics Explained; Eurostat Statistics Explained: Luxembourg, 2016; pp. 1-13.

53. Schultz, C.; Sjostrom, T. Public Debt, Migration, and Shortsighted Politicians. J. Public Econ. Theory 2004, 6, 655-674. [CrossRef]

54. Aceleanu, M.; Serban, A.; Burghelea, C. "Greening" the Youth Employment-A Chance for Sustainable Development. Sustainability 2015, 7, 2623-2643. [CrossRef]

55. Watt, P. Financing Local Government. Local Gov. Stud. 2004, 30, 609-623. [CrossRef]

56. Sáiz, M.P. La Ley de Economía sostenible: la sostenibilidad financiera del sector público. Rev. Contab. y Dir. 2011, 13, 21-41.

57. Estevez, E.; Janowski, T. Electronic Governance for Sustainable Development-Conceptual framework and state of research. Gov. Inf. Q. 2013, 30, S94-S109. [CrossRef]

58. Bank of Spain. Boletín Estadístico 12/2014; Bank of Spain: Madrid, Spain, 2014.

59. Ministry of Finance and Public Administration Proyecto Presupuestos Generales de las Comunidades Autónomas 2014 -; Ministry of Finance and Public Administration: Madrid, Spain, 2014.

60. Benito, B.; Vicente, C.; Bastida, F. The impact of the Housing Bubble on the growth of municipal debt: Evidence from Spain. Local Gov. Stud. 2015, 41, 997-1016. [CrossRef]

61. INE Spanish Statistical Office. Available online: www.ine.es (accessed on 15 January 2019).

62. Fundación La Caixa. Informe Anual Memoria Sostenibilidad 2013; Fundación La Caixa: Barcelona, Spain, 2013.

63. Rodríguez, M.P.; López, M.D.; Alcaide, L.; Navarro, A. The EU's Concern About the Influence of Demographic Factors on Financial Sustainability. In Financial Sustainability in Public Administration: Exploring the Concept of Financial Health; Rodríguez Bolívar, M.P., Ed.; Springer International Publishing: Cham, Germany, 2017; pp. 85-108, ISBN 978-3-319-57962-7.

64. NAO. Financial Sustainability of Local Authorities. Department for Communities and Local Government; The Stationery Office: London, UK, 2014.

65. Zhu, L. Panel Data Analysis in Public Administration: Substantive and Statistical Considerations. J. Public Adm. Res. Theory 2013, 23, 395-428. [CrossRef]

66. Zeedan, R.; Vigoda-Gadot, E.; Ben-Artzi, Y. Causes of (and Solutions for?) Financial Crises in Local Governments Insights From Local Arab Authorities in Israel. Adm. Soc. 2014, 49, 1065-1083. [CrossRef]

67. Wooldridge, J.M. Introductory Econometrics: A Modern Approach, 5th ed.; Cengage Learning: Mason, VA, USA, 2009.

68. Dosi, G. Sources, Procedures, and Microeconomic Effects of Innovation. J. Econ. Lit. 1988, 26, 1120-1171. 
69. Prillaman, S.A.; Meier, K.J. Taxes, Incentives, and Economic Growth: Assessing the Impact of Pro-business Taxes on U.S. State Economies. J. Polit. 2014, 76, 364-379. [CrossRef]

70. Arellano, M.; Bover, O. Another look at the instrumental variable estimation of error-components models. J. Econom. 1995, 68, 29-51. [CrossRef]

71. Blundell, R.; Bond, S. Initial conditions and moment restrictions in dynamic panel data models. J. Econom. 1998, 87, 115-143. [CrossRef]

72. Roodman, D. How to xtabond2: An introduction to difference and system GMM in Stata. Stata J. 2009, 9, 86-136. [CrossRef]

73. Windmeijer, F. A finite sample correction for the variance of linear efficient two-step GMM estimators. J. Econom. 2005, 126, 25-51. [CrossRef]

74. Baum, C.F.; Schaffe, M.E.; Stillman, S. Instrumental variables and GMM: Estimation and testing. Stata J. 2003, 3, 1-31. [CrossRef]

75. Arellano, M.; Bond, S. Some tests of specification for panel data: Monte Carlo evidence and an application to employment equations. Rev. Econ. Stud. 1991, 58, 277. [CrossRef]

76. Hansen, L.P. Large Sample Properties of Generalized Method of Moments Estimators. Econometrica 1982, 50, 1029-1054. [CrossRef]

77. Kasymova, J. Understanding the Challenges and Sustainability of Citizen Engagement in the Budgeting Processes of Developing Countries. Adm. Soc. 2014, 49, 374-393. [CrossRef]

(C) 2019 by the authors. Licensee MDPI, Basel, Switzerland. This article is an open access article distributed under the terms and conditions of the Creative Commons Attribution (CC BY) license (http://creativecommons.org/licenses/by/4.0/). 